\title{
Tool Wear and Machinability of Wood-based Materials during Machining Process
}

Eva Šebelová, Josef Chladil

Department of Furniture, Design and Habitat, Mendel University in Brno, Zemědělská 1, 61300 Brno, Czech Republic. eva.sebelova@mendelu.cz

The article is focused on the machinability classification of wood-based materials resulting from experimental work targeted on the wear procedure of cutting edge. These types of materials are not currently classified into groups of machinability. Two representatives of the materials - laminated chipboard (DTD-L) and medium density fibreboard (MDF) were tested in the project. The process of material classification from the view point of machinability is well processed in engineering materials contrary to materials from wood processing. Experimental measurements were based on the determination of the radial tool wear. Tested materials were included according to achieved results in the material groups and their relevant classes. One of the most important classification indicators was the index of kinetic machinability $\mathrm{K}_{\mathrm{v}}$. Material DTD-L has been selected as a reference sample - standard as the material most often used in woodworking industry.

Key words: machinability, tool wear, life-time, class of machinability.

\section{Acknowledgement}

The work has been supported by Internal Grant Agency (IGA) of Mendel University, reg. no. 33/2012 and 63/2013 and the European Social Fund and the state budget of the Czech Republic, project "The Establishment of an International Research Team for the Development of New Wood-based Materials" reg. no. CZ.1.07/2.3.00/20.0269.

\section{References}

[1] BÍLEK, O., LUKOVICS, I., ROKYTA, L. Manufacturing of Thermoplastics and Chip Formation. Chemické listy, 2011 , vol. 105, no. 15 S.ISSUE, pp. 317-319. ISSN 0009-2770.

[2] BÍLEK, O., ROKYTA, L., ŠIMONÍK, J. CAM in the Production of Casting Patterns. Manufacturing Technology, 2012 , vol. 12, no. June 2012, pp. 7-12. ISSN 1213-2489.

[3] BUMBÁLEK, B. Material Machinability - Decisive Factor for Development of Machining Technology and Creation of Technological Databank Informations. Manufacturing Technology, 2001, vol. 1, no. January 2001, pp. 3-10. ISSN 1213-2489.

[4] CSANÁDY, E.; MAGOSS E.. Mechanics of wood machining. 2nd ed., New York: Springer, 2012, pp. 199, ISBN 978-3-64229954-4.

[5] DOWDY, S., WEARDEN S.; CHILKO D. Statistics for research. 3rd ed. /. Hoboken, N.J.: Wiley-Interscience, c2004, xvi, pp. 627. ISBN 04-712-6735-X.

[6] CHLADIL J. Problems of cutting tool design for wooden shaped surfaces, In: Annals of DAAAM for 2005 \& Proceedings „Inteligent Manufacturing \& Automation“, pp. 067-068, DAAAM International Vienna, Opatia, 2005, ISBN 3-901509-46-1.

[7] CHLADIL, J. Otupení nástrojů při obrábění materiálů na bázi dřeva. In Nástroje 2006 - V. International Tool Coference. 1. vyd. Zlín: UTB Zlín, 2006, pp. 5, ISBN 80-7318-448-6

[8] CHLADIL, J. Rychlostní poměry při CNC obrábění rovinných křivek. Strojírenská technologie, 2010, roč. XV., č. 3, pp. 4851. ISSN 1211-4162.

[9] CHLADIL, J.: Problems of cutting tool solution for wooden based profile production, In: Trieskové a beztrieskové obrábanie dreva '04, Starý Smokovec, October 2004, pp. 105-111, ISBN 80-228-1385-0.

[10] KOCMAN, K. Technologické procesy obrábění. Vyd. 1. Brno: Akademické nakladatelství CERM, 2011, pp. 330, ISBN 97880-7204-722-2.

[11] KOCMAN, K., PROKOP, J. Cutting Tools for Hard Material Turning. Manufacturing Technology, 2004, vol. 4, no. October 2004, pp. 5-10. ISSN 1213-2489.

[12] SHAW, M.C. Metal Cutting Principles, 2nd ed., Oxford university press, New York, Oxford, 2005, pp. 651, ISBN 0-19514206-3.

[13] VASILKO, K. The Wood requires Orthogonal Cutting. Manufacturing Technology, 2010, vol. 10, no. December 2010, pp. 3945. ISSN 1213-2489. 